\title{
Assessment of flood vulnerability in the Bodva catchment using multicriteria analysis and geographical information systems
}

\author{
M. Zeleňáková ${ }^{1}, \mathrm{P}$. Blistan $^{2} \& \mathrm{P} . \mathrm{Purcz}^{3}$ \\ ${ }^{1}$ Institute of Environmental Engineering, \\ Technical University of Košice, Slovakia \\ ${ }^{2}$ Institute of Geodesy, Cartography and Geographical \\ Information Systems, Technical University of Košice, Slovakia \\ ${ }^{3}$ Institute of Construction Technology and Management, \\ Technical University of Košice, Slovakia
}

\begin{abstract}
The identification of flood vulnerability consists of two basic phases. Firstly, the effective factors causing floods are identified. Secondly, approaches to multicriteria analysis (MCA) in a geographical information system (GIS) environment are applied and these approaches are evaluated in order to prepare a flood vulnerability map. In the analyses, the main causative factors for flooding in a basin area are taken into account, such as soil type, daily precipitation, land use, size of the catchment and basin slope. A case study of flood vulnerability identification in the Bodva river basin in eastern Slovakia is presented in the paper.
\end{abstract}

Keywords: flood, analytical hierarchy process, casual factors.

\section{Introduction}

After the floods in the summer of 2002 several member states of the European Union directed the attention of the Council of the European Union on the problem of prevention and protection from floods. In October 2004 the Council agreed with their proposal that member states coordinated by the European Commission prepare European action in flood mitigation program which after appropriate legislative processes will become a common, binding legal 
instrument for all states of the European community, issued on the basis of conformity of the positions of the European Parliament and Council. On 23 October 2007, this initiative led the European Parliament and European Council to the acceptance of directive 2007/60/EC on the assessment and management of flood risks [1]. The purpose of the directive is to determine a framework for the assessment and management of flood risks on the level of the Community, with the goal of reducing the adverse consequences of floods on human health, the environment, economic activities and cultural heritage. For achieving the goals of directive 2007/60/EC, which is implemented in the legislative of the Slovak Republic in Act no. 7/2010 on the flood protection [2] the obligation was placed on all member states to work up a preliminary flood risk assessment (PFRA), which was completed in December 2011; to prepare maps of flood hazard areas and maps of flood risk, which were completed in 2013; and by the year 2015 to work up plans for management of flood risk. Subsequently, the individual steps must then be updated every 6 years.

In the last decade, Slovakia is being increasingly affected by floods (Zeleňáková $[3,4])$. Floods constantly point to the fact that the society is very vulnerable but it has been proved that flood-related problems could be solved through planning studies and detailed projects about flood prone areas (Hanák and Korytárová [5], Hlavčová et al. [6], Korytárová et al. [7], Solín [8]). The causes of flooding are extremely heavy rains or rapid melting of snow combined with a significantly reduced ability to detain stormwater in areas. The negative human-based factors cause changes in runoff ratio and increase the risk of flooding.

Flood risk analysis provides a rational basis for prioritizing resources and management actions mainly in the flood vulnerable areas. Risk analysis can take many forms, from informal methods of risk ranking and risk matrices to fully quantified analysis (Hall [9]). Tools like flood risk mapping, risk-based design of flood protection measures, flood insurance, and similar are given detailed consideration in the context of integrated flood risk management (Simonovic [10]). Multicriteria analysis (MCA) methods and geographical information systems have been successfully applied in several studies in flood risk assessment (Yalcin and Akyurek [11], Meyer et al. [12], Yahaya et al. [13], Kandilioti and Makropoulos [14]).

The aim of the presented study is to evaluate the applicability of MCA Analytic Hierarchy Process (AHP) for the flood vulnerability assessment under the specific conditions of eastern Slovakia - Bodva river basin and to generate a composite flood vulnerability map of this river basin mainly for the decision makers in the field of river basin management.

\section{Study area}

Bodva river basin (Fig. 1) is situated in the southwestern part of the Kosice region. The river Bodva rises in the mountains Volovske hills, on the northeastern slope of the hill Osadník (1186 m asl.). The whole area of Kosice region belongs into the zones of Inner Western Carpathians. Geological structure 
of the area forms the hydrogeological conditions of the sub-basin Bodva. Older Paleozoic rocks whose original character before metamorphosis was volcanic with intergranular permeability are characteristic by fissure permeability. There is a predominance of heavy loamy soils that occupy contiguous area of Košice basin. Sandy-loam soils occupy forests in the mountains Volovske hills and partially Slovak Karst.

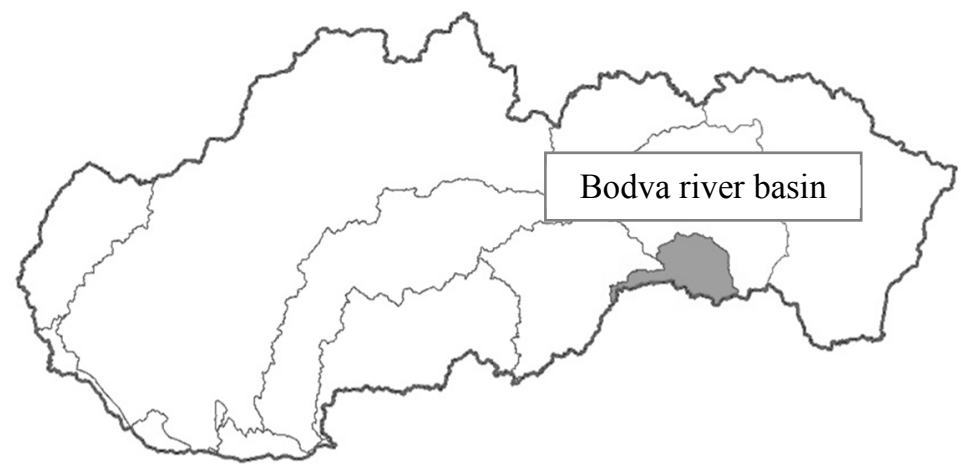

Figure 1: $\quad$ Study area - Bodva river basin.

The orographic condition range from $168 \mathrm{~m}$ asl. (Host'ovce) to $1186 \mathrm{~m}$ asl (Osadník). Height and slope conditions affect climatic conditions, especially the size and distribution of rainfall, the air temperature and thus on the overall water balance and runoff regime. Sub-basin Bodva regarding the complex orographic ratio ranges into several climatic zones. South and east part - the largest part of basin belongs to warm climate, which is and slightly damp with cold winters. Long-term average annual air temperatures range from $5^{\circ} \mathrm{C}$ to $8^{\circ} \mathrm{C}$. Long-term annual average annual precipitations in the basin range from 600 to $1000 \mathrm{~mm} . \mathrm{r}^{-1}$.

In terms of precipitation especially year 2010 was extremely above average and with significantly unequal in distribution of rainfall in each month in all regions of Slovakia as well as in Bodva river basin. These rainfall conditions had a significant impact on the environment, catchment saturation and hence the overall flood situation on extreme flows in Slovakia, also a significant increase in groundwater levels (Zeleňáková et al. [15]).

Preliminary flood risk assessment which has been done by Water Research Institute in the Slovak Republic in cooperation with Slovak Water Management Company in 2011 identified the geographical areas with potentially significant flood risk. In the sub-basin Bodva were identified two geographical areas with existing potentially significant risk - Medzev and Jasov and three geographical areas with probably potentially significant risk - Košice-Šaca, Vel'ká Ida and Moldava nad Bodvou MoE and WRI [16].

In this study, we analysed flood vulnerability in Bodva river basin based on identifying the main factors causing floods that were identifying according the expert consultations and literature sources studying. Then we applied method of MCA - Analytical Hierarchy Process (AHP) for statement of factors significance 
(Zeleňáková and Gaňová [17]). Finally we were evaluating the flood vulnerability of the area using GIS tools - kriging method in ArcGIS software.

\section{Materials and methods}

The first step in assessing the vulnerability structure as was mentioned was to identify the factors affecting flooding on the basis of an analysis of existing studies and knowledge (Gaňová et al. [18]). We use set of causative factors concerning mostly hydrological and geographical characteristics of the target area that can be measured and evaluated. The factors used in this study were selected due to their relevance in the study area. The initial data required for this study were acquired from relevant resources and institutions in the Slovak Republic. These include following:

- Monthly rainfall obtained from Slovak Hydrometeorological Institute;

- Soil type obtained from Soil Science and Conservation Research Institute;

- Basin slope obtained from Digital Terrain Model;

- Land use obtained from Corine Land Cover;

- Catchment area obtained from Slovak Water Management Enterprise.

The data needed in this study were produced from collected or existing data using different kinds of spatial functions and analysis. GIS was applied for managing, producing, analyzing and combining spatial data. ArcGIS 10.2 was used for transferring data to the appropriate GIS layers.

Each factor was divided into classes. Inverse ranking was applied to importance of factor's classes, with the least important $=1$, next least important $=2$, etc. The limit value belongs to higher class. This classification shall enter into a narrative or numeric character, as is shown in Table 1.

The method for determining flood vulnerability is the Analytic Hierarchy Process (AHP). The analytical hierarchy process (AHP) is a flexible and yet structured methodology for analyzing and solving complex decision problems by structuring them into a hierarchical framework (Saaty [19]). The AHP procedure is employed for rating/ranking a set of alternatives or for the selection of the best in a set of alternatives. The ranking is done with respect to an overall goal, which should be broken down into a set of criteria (objectives, attributes) (Boroushaki and Malczewski [20]).

Twelve river stations in the river basin were assessed. For each river station a matrix 5 x 5 - factors x class $(1-5)$ was established. An example of a completed matrix for river station Stós is shown in Table 2.

This matrix was completed with values from 1 to 5 , depending on the class of each factor for the relevant river station in the following way: e.g. when a river station is located in an area where rainfall is class one, the number 1 is written in column " 1 " for the line "rainfall", and other values on this line are zero. In this way the whole matrix was completed for all factors. Factor's classes are usually proposed based on expert knowledge, which however is still the subjective method, which cannot be applied elsewhere. We solved this problem of weighting the factors' classes using the calculation of entropy. 
Table 1: Factor's class and its importance.

\begin{tabular}{|c|c|c|}
\hline Factors & Factor's classes & $\begin{array}{c}\text { Importance of factor's } \\
\text { class }\left(I F_{\mathrm{i}, \mathrm{j}}\right)\end{array}$ \\
\hline $\begin{array}{l}\text { Monthly rainfall } \\
\text { in } \mathrm{mm}\end{array}$ & $\begin{array}{c}0-55 \\
55-60 \\
60-64.9 \\
65.0-69.9 \\
70.0 \text { and more }\end{array}$ & $\begin{array}{l}1 \\
2 \\
3 \\
4 \\
5\end{array}$ \\
\hline $\begin{array}{c}\text { Soil type } \\
\text { (content of clay } \\
\text { particles) } \\
\text { in } \%\end{array}$ & $\begin{array}{c}0-10 \\
10-30 \\
30-45 \\
45-60 \\
60 \text { and more }\end{array}$ & $\begin{array}{l}1 \\
2 \\
3 \\
4 \\
5\end{array}$ \\
\hline $\begin{array}{l}\text { Basin slope } \\
\text { in } \%\end{array}$ & $\begin{array}{c}0-15 \\
15-30 \\
30-45 \\
45-80 \\
80 \text { and more } \\
\end{array}$ & $\begin{array}{l}1 \\
2 \\
3 \\
4 \\
5\end{array}$ \\
\hline Land use & $\begin{array}{c}\text { forest } \\
\text { pastures and meadows } \\
\text { agricultural land } \\
\text { urbanized area } \\
\text { water area }\end{array}$ & $\begin{array}{l}1 \\
2 \\
3 \\
4 \\
5\end{array}$ \\
\hline $\begin{array}{l}\text { Catchment area } \\
\text { in } \mathrm{km}^{2}\end{array}$ & $\begin{array}{c}0-10 \\
10-50 \\
50-100 \\
100-200 \\
200 \text { and more }\end{array}$ & $\begin{array}{l}1 \\
2 \\
3 \\
4 \\
5\end{array}$ \\
\hline
\end{tabular}

Table 2: $\quad$ Matrix for AHP assessment.

\begin{tabular}{|c|c|c|c|c|c|c|}
\hline \multirow{3}{*}{ Station } & \multirow{5}{*}{ Factor } & \multicolumn{5}{|c|}{ Class } \\
\cline { 2 - 7 } & & $\mathbf{1}$ & $\mathbf{2}$ & $\mathbf{3}$ & $\mathbf{4}$ & $\mathbf{5}$ \\
\hline \multirow{3}{*}{ Štós } & Daily rainfall & 0 & 2 & 0 & 0 & 0 \\
\cline { 2 - 7 } & Soil type & 0 & 0 & 3 & 0 & 0 \\
\cline { 2 - 7 } & Land use & 0 & 2 & 0 & 0 & 0 \\
\cline { 2 - 7 } & Basin slope & 1 & 0 & 0 & 0 & 0 \\
\cline { 2 - 7 } & Size of watershed & 0 & 0 & 3 & 0 & 0 \\
\hline
\end{tabular}


The AHP method programmed in Microsoft Excel was used to determine the weighting of each river station. Matrices were developed for all twelve river stations in Bodva river basins. From the results calculated for separated stations was done interpolation by kriging method (using extension geostatical analyst) $[21,22]$ in ArcGIS 10.2 for the whole area of the Bodva river basin.

\section{Results and discussion}

The flood vulnerability was evaluated in four classes according Table 3.

Table 3: Vulnerability acceptability.

\begin{tabular}{|c|c|c|}
\hline Vulnerability rate & Vulnerability acceptability & Scale of vulnerability \\
\hline 1 & acceptable & $0.050-0.065$ \\
\hline 2 & moderate & $0.066-0.080$ \\
\hline 3 & undesirable & $0.081-0.095$ \\
\hline 4 & unacceptable & 0.096 and more \\
\hline
\end{tabular}

The resultant weightings with AHP for all river stations are shown in Table 4. River stations are ranked by the value of weightings from largest to smallest.

Table 4: Resultant weightings for river stations.

\begin{tabular}{|c|c|}
\hline River station & Weight \\
\hline Štos & 0.051097 \\
\hline Zlata Idka & 0.051097 \\
\hline Perín & 0.051097 \\
\hline Jablonov nad Turňou & 0.071072 \\
\hline Malá Ida & 0.080109 \\
\hline Košice-Šaca & 0.090646 \\
\hline Kečovo & 0.087918 \\
\hline Moldava nad Bodvou & 0.090646 \\
\hline Jasov & 0.103193 \\
\hline Janík & 0.103598 \\
\hline Turňa nad Bodvou & 0.108868 \\
\hline Silica & 0.110658 \\
\hline
\end{tabular}

The obtained result from software ArcGIS 10.2 - map of flood vulnerability for Bodva river station is presented in Figure 2. 


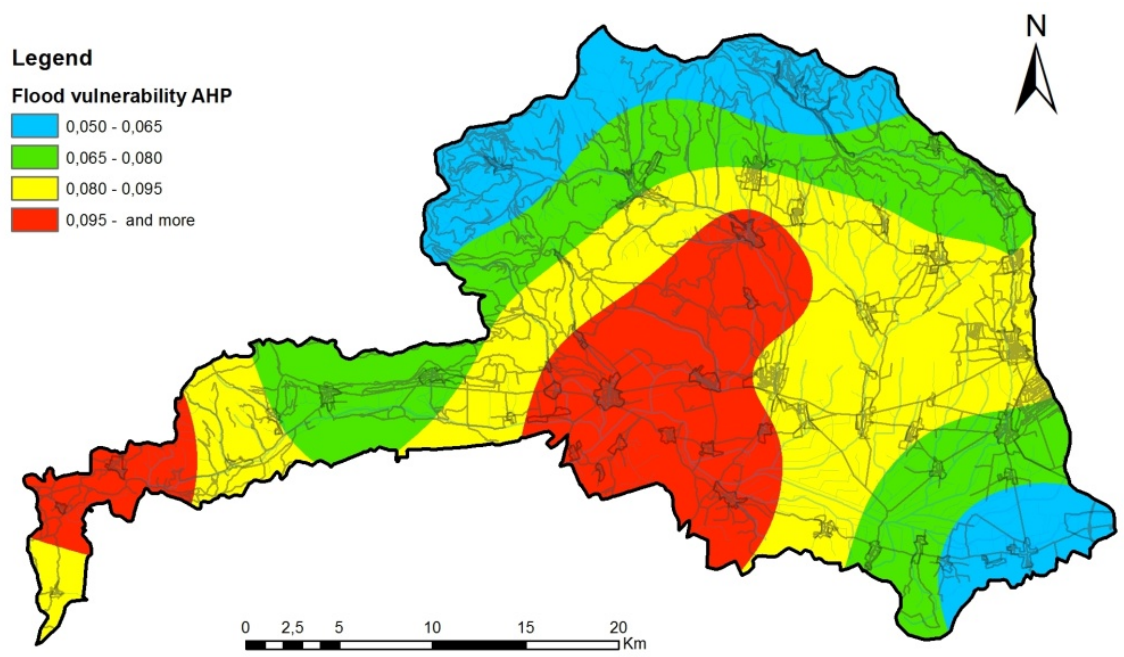

Figure 2: Map of flood vulnerability in the study area based on the analytic hierarchy process.

The flood vulnerability assessment based on the analytic hierarchy process shows which territory in Bodva watersheds is more vulnerable due to floods.

The undesirable and unacceptable levels of flood vulnerability were found in middle part of river basin. Unacceptable, the highest level of flood vulnerability, the most prone areas to floods represents $22.1 \%$ of the study area. Undesirable level of flood vulnerability was identified in $34.5 \%$ of the area. The moderate vulnerability zone and the acceptable flood vulnerability are mainly in the upper part of river basin. It covers $43.4 \%$ of the basin. The evaluation is based on factors classes from Table 1 as well as scale of vulnerability from Table 3 . If the division of classes or scale will be different the results will be also different. The most important and the aim of evaluation was to state the flood vulnerable area. It means which areas in the river basin are most vulnerable to floods regarding mainly hydro-pedological and geographical characteristics and land use. We assessed where in the Bodva basin is the highest necessity for flood mitigation measures - in the middle of the river basin.

\section{Conclusion}

The aim of flood risk management is the proposal of flood protection measures. The main objective of management as well as the entire management cycle is regulated by the Directive of the European Parliament and of the Council $2007 / 60 / \mathrm{EC}$ on the assessment and management of flood risks. The aim of this directive is to reduce and control the adverse consequences on human health, the environment, cultural heritage and economic activity associated with floods. 
The objective of the paper is to propose a methodology which could be used for preliminary flood risk assessment of floods.

Basically two phases are applied in this study to analyze flood vulnerability: firstly to identify the effective factors causing floods - the potential natural causes of flooding, and secondly to apply methods of MCA in GIS environment to evaluate the flood vulnerability of the area.

The flood vulnerable areas in the study area Bodva watershed were evaluated in four classes. Since the methods take into account some conditions of the region, the results can be as realistic only for this condition. When the characteristics would change, the results will show the different results. The subjective numbers in the weights and the values of the criteria can be changed according to the study area characteristics and experts' opinions. Our pilot study showed the possibility of using MCA and GIS for flood vulnerability assessment.

\section{Acknowledgement}

This paper was written thanks to support from project VEGA 1/0609/14.

\section{References}

[1] Directive 2007/60/EC of the European Parliament and of the Council of 23 October 2007 on the assessment and management of flood risks.

[2] Act no. 7/2010 of Slovak republic of 27 October 2004 on the flood protection.

[3] Zeleňáková, M., Preliminary flood risk assessment in the Hornád watershed. In: River Basin Management 5, Ramla Bay Resort, Malta. Southampton: Wessex Institute of Technology, pp. 15-24, 2009.

[4] Zeleňáková, M., Flood risk assessment and management in Slovakia. In: River Basin Management 6, Riverside, California, USA. Southampton: WIT, pp. 61-69, 2011.

[5] Hanák, T., Korytárová, J., Risk zoning in the context of insurance: Comparison of flood, snow load, windstorm and hailstorm. Journal of Applied Engineering Science. Vol. 12, pp. 137-144, 2014.

[6] Hlavčová, K., Kohnová, S., Kubeš, R., Szolgay, J., Zvolenský, M., An empirical method for estimating future flood risk for flood warnings. In Hydrology and Earth System Sciences, Vol. 9, No. 4, pp. 431-488, 2005.

[7] Korytárová, J, Šlezingr, M, Uhmannová, H., Determination of Potential Damage to Representatives of Real Estate Property in Areas Afflicted by Flooding. Journal of Hydrology and Hydromechanics, Vol. 55, pp. 282-228, 2007.

[8] Solín, L., Spatial variability in the flood vulnerability of urban areas in the headwater basins of Slovakia. Journal of Flood Risk Management, Vol. 5, pp. 303-320, 2012.

[9] Hall, J., Journal of Flood Risk Management, Journal of Flood Risk Management, Vol. 3, pp. 1-2, 2010. 
[10] Simonovic, S. P., Managing flood risk, reliability and vulnerability. Journal of Flood Risk Management, Vol. 2, pp. 230-231, 2009.

[11] Yalcin, G., Akyurek, Z., Analysing flood vulnerable areas with multicriteria evaluation, In: Geo-Imagery Bridging Continents, XXth ISPRS Congress, <http://proceedings.esri.com/library/userconf/proc04/ docs/pap1097.pdf>, pp. 359-364, 2004.

[12] Meyer, V., Scheuer, S., Haase, D., A multicriteria approach for flood risk mapping exemplified at the Mulde river, Germany. Natural Hazard, Vol. 48, No. 1, pp. 17-39, 2009.

[13] Yahaya S., Ahmad N., Abdalla F. R., Multicriteria Analysis for Flood Vulnerable Areas in Hadejia-Jama'are River Basin, Nigeria. European Journal of Scientific Research, Vol. 42, No. 1, pp. 71-83, 2010.

[14] Kandilioti G., Makropoulos Ch., Preliminary flood risk assessment. The case of Athens, Natural Hazards, Vol. 61, No. 2, pp. 441-468, 2012.

[15] Zeleňáková, M., Zvijáková, L., Gaňová L., Environmental impact study Bodva river basin. In: Water resources and wetlands: 2nd International Conference: 11-13 September 2014, Tulcea, Romania. Targoiste: Transversal publishing house, pp. 329-335, 2014.

[16] MoE (Ministry of Environment), SWME (Slovak Water Management Enterprise), Implementation of directive 2007/60/ES of 23rd October 2007 on flood risk assessment and management: Preliminary flood risk assessment in Bodrog river basin, Attachments [online]. December 2011 [Available from: http://www.minzp.sk/files/sekcia-vod/bodrog-prilohy.pdf

[17] Zeleňáková, M., Gaňová, L., Integrating multicriteria analysis with geographical information system for evaluation flood vulnerable areas. In: 11th International Multidisciplinary Scientific GeoConference (SGEM), Albena, Bulgaria, pp. 433-440, 2011.

[18] Gaňová, L., Zeleňáková, M., Purcz, P., Flood Hazard Assessment in Eastern Slovakia. Discovery. Vol. 22, pp. 32-36, 2014.

[19] Saaty, T. L. The Analytic Hierarchy Process: Planning, Priority Setting, Resource Allocation, New York: McGraw-Hill International Book Co., p. 437, 1980.

[20] Boroushaki, S., Malczewski, J., Implementing an extension of the analytical hierarchy process using ordered weighted averaging operators with fuzzy quantifiers in ArcGIS, Computers \& Geosciences, Vol. 34, pp. 399-410, 2008.

[21] Blišt'an, P., Interpolation methods for modeling and visualization of spatial phenomena in GIS environment. Fyzikálne faktory prostredia. Vol. 2, pp. 99-105, 2012.

[22] Stein, M. L., Interpolation of Spatial Data. Springer-Verlag New York, p. $247,1999$. 